\title{
Virtual Discussion for EFL Students Establishing Three Domains: Cognitive, Affective, and Psychomotor
}

\author{
Ike Dian Puspita Sari ${ }^{1, a^{*}}$, and Tities Hijratur Rahmah ${ }^{1, b}$ \\ ${ }^{1}$ Department of English Education, Faculty of Social Education and Humanities, IKIP Budi Utomo Malang, Indonesia \\ a ikedianpuspitasari@gmail.com; b hijraturrahmah@gmail.com \\ *Corresponding Author \\ Whatsapp Number [+62-813 3021 1770]
}

How to Cite: Sari, I., D., P. Rahmah, T., H. (2019). Virtual Discussion for EFL Students Establishing Three Domains: Cognitive, Affective, and Psychomotor. International Journal for Educational and Vocational Studies, 1 (3), 249-253.

\section{ARTICLE HISTORY}

Received: 10 June 2019

Revised: 14 July2019

Accepted: 21 July 2019

\section{KEYWORDS}

Virtual Discussion,

Cognitive,

Affective,

Psychomotor

\section{ABSTRACT}

In teaching and learning process, teacher may use certain learning strategies or methods. Virtual discussion, for instance, it can be done to encourage students' cognitive, affective, and psychomotor. This activity provides an opportunity for students to sit and listen as they speak and think critically, logically, and rationally. Moreover, students get better results when they work together than those who study individually. This survey research conducted to find out the correlation among virtual discussion with cognitive, affective, and psychomotor of 110 students in IKIP Budi Utomo Malang. The result shows that the virtual discussion has strong correlation not only in cognitive domain, but also it has strong correlation with affective and psychomotor domain. Almost all significant values are positive. There is only one negative significant value between cognitive and affective. Thus, it illustrates that the increasing of cognitive domain by applying virtual discussion is not always followed by the increasing of affective domain.

This is an open access article under the CC-BY-SA license.

\section{INTRODUCTION}

In the learning process, teacher has an important role to design, supervise and evaluate learning outcomes. According to Rani \& Archana (2017), there are several teaching roles in the process of learning English, namely as facilitators, supervisors, managers, evaluators, and even have a role as students. As a facilitator, the teacher has a role to develop a learning environment that refers to social life, intellectual intelligence, and awareness of language use. An assignment to students is a learning plan to make students master English skills. In an evaluation, the teacher will refer to the competencies that have been achieved, compared to the weaknesses of the students.

The three domains that are taken into consideration in seeing the output of learning, namely cognitive, affective, and psychomotor domains (Hoover, et. al., 2010). According to Smith in Micklich (2011), cognitive domains are implemented in learning activities, such as remembering, thinking, solving problems, and creating or producing something. While the affective domain focuses on the arising and desires of learning that arise in students. According to Hoover and Giambatista (2009), psychomotor domain increases the interest of learning, - where this domain is a dimension that can continuously activate a learning environment that has high intensity to improve learning outcomes. This domain can be applied in giving assignments to students.

According to Alinier \& Alinier (2005), cognitive domain related to how students master the learning process and apply the knowledge they got. The level of cognitive domains can be measured through class discussion, compiling lesson notes, getting tutorial activities, using teaching materials in the form of charts, using Power point slides, giving authentic examples, provision of quizzes, project/problem based learnings, procurement of seminars, giving questions which answers are in the form of explanations or descriptions (Kasilingam et. al, 2014). This domain leads to intellectual abilities. In contrast to cognitive domain, affective domain is domains that focuses on behavior, motivation, the desire to participate, evaluation of what has been learned, to then be associated with values in real life (Kasilingam, et. al., 2014). He also mentions the levels of the affective domain, such as receiving (desire to listen), responding, assessing (desire to be involved), organizing (desire to be an idea maker), 
and grouping and describing (the desire to change people's lifestyles or ways of thinking). He also mentions the psychomotor domain refers to motor activities related to accuracy, fluency, and speed. The steps in the psychomotor domain, starting from action, coordination, formation, and production.

Giving assignments in the learning process that refers to these three domains can be done in several ways. Interactive assignments can be done so that all three domains (cognitive, affective, and psychomotor) can be achieved. One of them, for example through discussion activities. Discussions can be made between students and other students or with teachers. This activity provides an opportunity for students to sit and listen as they speak and think critically, logically, and rationally (Eaton \& Beecher, 2007).

According to Brookfield in Rahmat (2017), the benefits of group discussion include: a). to familiarize students in cultivating perspectives and finding new perspectives, b). to improve intellectual ability and to improve students' listening skills, c). to increase student interest and relate it to a topic of discussion, d). to show students that thinking and experiencing directly is very useful, e). to help students to develop the ability to work in a team, f). to increase democratic sense and respect other people's opinions and tolerance for differences, g). to make students to be responsible for their abilities, and h). to improve the ability of students to lead and to be led.

In modern era, the use of technology can be used to support the learning process. Scivenerr in Boumova (2008) asserts that learning occurs when students are able to engage, speak, interact and carry out the learning process according to their desires and abilities. Students are able to access information quickly through internet access. Not often, they exchange information with other students through the sophistication of their mobile features. Such a phenomenon leads students to hold virtual discussions to get the information they want.

Virtual Learning Environment (VLEs) is a basic component in distance learning, but it can be integrated with face-to-face learning (Dillenbourg, 2000). In system of VLEs, learning can be done by sending or exchanging information through website pages, e-mails, electronic messages, virtual discussions, video conferences, and so on.

In the learning process, it cannot be denied if students interact with each other both directly and virtually. The students can carry out learning activities using authentic communication tools (Hason-Smith, 2001). The activity is very effective because students can exchange information quickly. The virtual community is interpreted as a dynamic amalgamation between several people in sharing certain knowledge. The form of virtual learning makes students create the benefits of effective social interaction and cognitive development (Palloff \& Pratt, 2007).

A research conducted by Harizaj (2015) shows that discussion methods can facilitate speaking skills, and language skills of students through active learning.
Students get better results when they work together than those who study individually. A teacher should be able to create an interactive atmosphere and motivate students to participate. Information exchange activities can not only be done when students meet in person. However, these activities can be done virtually. Guaman (2012) conducted a qualitative study of state school students in Bogota who use Facebook as a virtual learning media. From the results of the analysis, students are able to express their opinions through conversations and uploads made. This is also reinforced by a research conducted by Kuama (2016). He conducted research on online learning called online learning strategies (OLLS). The number of research subjects was 346 students who took English courses online. Measurements were made for cognitive, metacognitive, understanding, and perceptions of the online learning approach. Significant results were found on cognitive and metacognitive domains. In this study, researchers will conduct a survey of IKIP Budi Utomo Malang students. Researchers want to know the extent of the relationship between virtual discussions conducted by students with cognitive, affective, and psychomotor domains that they have.

\section{MATERIALS AND METHODS}

\subsection{Research Design}

This study used a type of survey research design. Researcher examined the relationship among virtual discussions conducted in learning activities with three domains, namely cognitive, affective, and psychomotor. The researcher did not control the characteristics of the research subject, where the class used was not given a test first. In survey research design, researchers only collected the data needed in the form of several questions related to the focus of research. Virtual discussion is an independent variable $(\mathrm{X})$ in this study. While cognitive, affective, and psychomotor domains are dependent variables (Y). After collecting data from the results of student questionnaires, researchers analyzed it to find out the relationship between variables $\mathrm{X}$ to $\mathrm{Y}_{1}$ (Cognitive Domain), $\mathrm{Y}_{2}$ (Affective Domain), and $\mathrm{Y}_{3}$ (Psychomotor Domain).

\subsection{Research Subject}

The subject of this study consisted of 110 students. The researcher involved 110 IKIP Budi Utomo Malang students in the class of 2016. The research subjects were taken randomly by considering several factors, including the existence of virtual discussions conducted by the 2016 class students in learning activities.

\subsection{Research Instrument}

In order to produce valid data, researchers used research instruments. The researchers used a questionnaire consisting of 45 questions. The questionnaire uses a Likert scale with a range of 1-5 as a measure of the answers that must be given by the respondents (students). There are 15 
questions for each domain (cognitive, affective, and psychomotor).

\subsection{Hypothesis Testing}

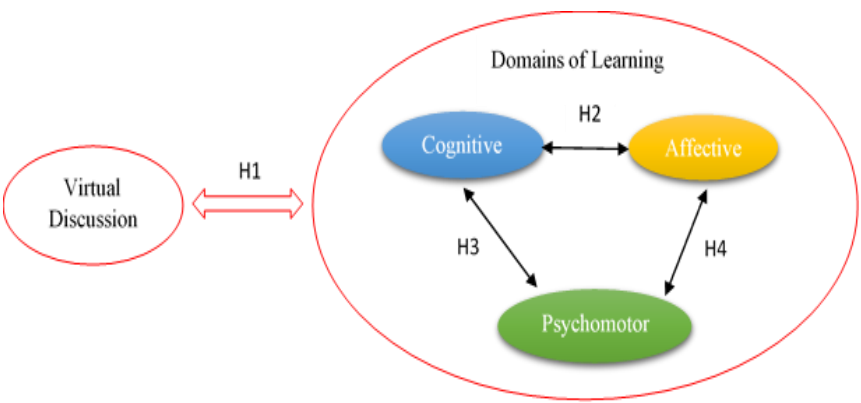

Figure 1. Hypothesis Testing

Based on previous research conducted by some researchers, virtual discussion affects significantly with cognitive, affective, and psychomotor domain. Thus, there are four hypothesis testing in this research. Those hypotheses are:

H1: There is significant correlation between virtual discussion towards domains of learning.

$\mathrm{H} 2$ : There is strong correlation between cognitive domain and affective domain.
H3: There is strong correlation between cognitive domain and psychomotor domain.

H4: There is strong correlation between affective domain and psychomotor domain.

\subsection{Statistical Analysis}

The questionnaire was validated by using SPSS 16.0. After each question in the questionnaire was valid, the researcher distributed to the students. The result of questionnaire was also analyzed by using SPSS 16.10 .

\section{RESULTS AND DISCUSSIONS}

This study involved 110 English language students of 2016 at the IKIP Budi Utomo Malang. The data used in the form of a questionnaire with 45 statements. There are 15 statements for each domain, namely cognitive, affective, and psychomotor domains. Questionnaire used Likert scale 1-5. The questionnaire distributed aimed to measure the relationship between virtual discussions conducted by students with their cognitive, affective, and psychomotor domains.

From the results of analyzing the correlation among virtual discussion with cognitive, affective and psychomotor, a table is obtained as follows:

Table 1. Data Analysis of Cognitive Domain

\begin{tabular}{|c|c|c|c|c|}
\hline & & Cognitive & Affective & Psychomotor \\
\hline \multirow{3}{*}{ Cognitive } & Pearson Correlation & 1 & -.026 & .033 \\
\hline & Sig. (2-tailed) & .000 & .790 & .732 \\
\hline & $\mathrm{N}$ & 110 & 110 & 110 \\
\hline \multirow{3}{*}{ Affective } & Pearson Correlation & -.026 & 1 & .162 \\
\hline & Sig. (2-tailed) & .790 & .000 & .090 \\
\hline & $\mathrm{N}$ & 110 & 110 & 110 \\
\hline \multirow{3}{*}{ Psychomotor } & Pearson Correlation & .033 & .162 & 1 \\
\hline & Sig. (2-tailed) & .732 & .090 & .000 \\
\hline & $\mathrm{N}$ & 110 & 110 & 110 \\
\hline
\end{tabular}

In the table, the cognitive domain shows a significance value of 0,000 , where the value is smaller than $\alpha=0.05$. It means that the virtual discussion affects significantly the cognitive domain of students. It also occurs in affective and psychomotor domain. Affective domain significant value is 0.000 , while the psychomotor significant value is also 0.000. Both domains are affected significantly by virtual discussion.

The pearson correlation in cognitive domain shows very strong correlation with virtual discussion with $\mathrm{r}=1$. Similar with cognitive domain, affective domain and psychomotor domain have very strong correlation with virtual discussion. It shows from the pearson correlation value of both domain $(r=1)$.

After found out the correlation between the three domains and virtual discussion. The further analysis will focus on the correlation among the cognitive domain, affective domain, and psychomotor domain. The three pearson correlation are varied. Those value shows how big the domains are affected each other. The first comparison between cognitive and affective shows negative value $(r=$

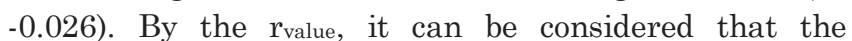
increasing or decreasing of cognitive domain is not followed by the increasing or decreasing of affective domain. Another comparison between cognitive and psychomotor shows positive value. Furthermore, it illustrates the increasing of cognitive domain is followed by the increasing of psychomotor domain. the $r_{\text {value }}$ between affective domain and psychomotor domain is 0.033. It shows very weak correlation. Hence, correlation between affective domain and psychomotor domain also shows positive value $(r=0.162)$. It means that the increasing of affective domain is not always followed by the increasing of psychomotor domain, although it can be considered as very weak correlation.

From the result, virtual discussion affects significantly the cognitive, affective and psychomotor domain. This 
analysis is supported by Khidzir et. al (2016) with their research related to Virtual Learning environments (VLEs) in Higher Learning Institution. By doing purposes sampling techniques, they found that all the three domains influence each other. They reveal that cognitive, affective, and psychomotor domain are affected by VLEs. The online discussion makes students interact as distance teaching and learning process. Zhu (2006) examined online discussion effect toward cognitive engagement by analyzing students' participation, interaction, and online teaching learning process. The online class discussion connected with teaching objectives. The result shows that online learning give a great impact for students' cognitive. It reveals by students' learning performance.

Cognitive domain correlates with human's thinking. It is related to recognition of what has been learnt and development of intellectual abilities. Bloom in Micklich (2011) mentions the activities of cognitive such as remembering and recalling knowledge, thinking, problem solving, and creating. The effect of online learning does not only affect students' cognitive. Based on the analysis between cognitive and affective domain, both domains do not correlate each other. It reveals that the increasing of cognitive domain is not followed by the increasing of affective domain. It also affects students' emotional and behavioral (Pilotti, 2017). However, the big class decreases the cognitive engagement and behavioral engagement. It might be affected by the opportunity to delivering ideas in online discussion. The opposite result occurs in instructors' engagement. When the class size increase, their cognitive and behavioral engagement also increases. It might be affected by the students' demand to get more knowledge.

The affective domain is related to human emotion. In this research, the correlation between affective domain and psychomotor domain is very weak. It might be affected by two points. Those are consciousness and awareness, and respond (Micklich, 2011). Bloom in Haque (2016) mentions the level of affective domain which is begun from knowledge engagement. In this level, students can define terms. The next level is comprehension, in which students can work assigned problems. The third level is analysis, in which it is problems solving step. At synthesis level, students may compile knowledge they know with the information they found. Finally, in the last level namely evaluation level, they can evaluate while establishing criteria to solve problems found in the end of teaching and learning process. In contrast to cognitive domain, affective domain is a domain that focuses on behavior, motivation, the desire to participate, evaluation of what has been learned, and then related to values in real life (Kasilingam, et. Al., 2014). This domain can support two other domains. Motivation and desire factors to participate in the learning process can give a positive impact on other domains. If their desires are strong, they will follow the learning process well.

According to Hoover and Giambatista (2009), psychomotor domains give rise to interest in learning, where this domain is a dimension that can continuously activate a learning environment that has high intensity to improve learning outcomes. Thus, the theory proves if psychomotor domains are related to the increase of affective domains. Psychomotor domain refers to motor activities related to accuracy, fluency, and speed (Kasilingam, et. Al., 2014). One activity that is related to the psychomotor domain is the assignment of tasks to students. The task can measure the accuracy, fluency, and speed of students during the learning process. While some theory describes the three domains related to each other.

\section{CONCLUSION}

The analysis shows that virtual discussion has strong correlation with cognitive, affective, and psychomotor domain. Positive correlation value illustrates the increasing of one domain followed by another domain. Cognitive domain increases while psychomotor domain increases. It also occurred in the correlation among affective with cognitive and psychomotor. They show synchronize increasing. The correlation among psychomotor domain with cognitive and affective are similar. There was only one negative significant value comparing cognitive domain, and affective domain. The increasing of cognitive domain when conducting virtual discussions is not followed by the increasing of affective domain.

Based on the result found, there are some factors which can be analyzed to reveal the increasing of cognitive domain which is not followed by the increasing of affective domain. Cognitive domain related to how students master the learning process and apply the knowledge they got. Furhermore, affective domain focuses on behavior, motivation, the desire to participate, evaluation of what has been learned, to then be associated with values in real life. Both domains should be related each other in teaching and learning process.

\section{REFERENCES}

Alinier N, Alinier G. (2005). Design of an Objective Assessment Tool to Evaluate Students' Basic Electrical Engineering Skills. The Higher Education AcademyEngineering Subject Centre.

Boumova, V. (2008). Traditional Vs. Modern Teaching Methods: Advantager and Disadvantages of Each. Master Diploma Thesis: Masaryk University.

Dillenbourg, P. (2000). Virtual Learning Environments. Presented at the EUN Conference 2000: Learning in the New Millennium: Building New Education Strategies for Schools.

Eaton, R., \& Beecher, M. (2007). The Art of Asking Question. In Becoming a Great Gospel Teacher. American Fork, UT: Covenant Communication.

Guaman, L. V. J. (2012). EFL Teenagers' Social Identity 
Representation in a Virtual Learning Community on Facebook. PROFILE, Vol. 14, No. 2, pp 181-193.

Hanson-Smith, E. (2001). Technology in the Classroom: Practice and Promise in the $21^{\text {st }}$ Century. TESOL Professional Paper 4.

Harizaj, M. (2015). Discussion as an Active Learning in EFL. European Scientific Journal, Vol. 11, No. 16, pp 231-236.

Hoover, R. et. al. (2010). Composition, molecular structure, properties, and modification of pulse starches: $A$ Review. Food Research International, Vol. 43, Issue 2 .

Hoover, J. D., \&Giambatista, R. G. (2009). Why Have We Neglected Vicarious Experiental Leaerning?. Developments in Simulation and Experiental Learning, Vol. 34, pp. 324-330.

Kasilingam, G, et. al. (2014). Assessment of Learning Domains to Improve Student's Learning in Higher Education. Journal of Young Pharamacists, Vol. 6, Issue 4, pp 27-33.

Khidzir, N. Z., Daud, K. A. M., \& Ibrahim, M. A. H. (2016). The Relationship among Student's Domai of Learning Development Implementing Virtual Learning in Higher Learning Institutions. International Journal of Information and Education Technology. Vol. 6 No. 6.

Kuama, S. (2016). Is Online Learning for All English Language Students?. PASAA, Vol. 52, pp 53-82.

Micklich, D. L. 2011. Examining the Cognitive, Affective, and Psychomotor Dimensions in Management Skill Development through Experimental Learning: Developing a Framework. Developemnt in Business Simulation and Experiential Learning, Vol. 38.

Palloff, R. \& Pratt, K. (2007). Building Online Leaerning Communities: Effective Strategies for the Virtual Classroom (2nd Edition). San Fransisco, CA: Jossey-Bass.

Pilotti, M., Anderson, S., \& Hardy, P. (2017). Factors Related to Cognitive, Emotional, and Behavioral Engagement in the Online Asynchronous Classroom. International Journal of Teaching and Learning in Higher Education. Vol 29 No. 1.

Rahmat, A. (2017). Small Group Discussion Strategy Towards Students'Reading Comprehension of SMA Negeri 11 Bulukumba. METATHESIS, Vol 1, No.

Rani, K. U., \& Archana, S. (2017). Role of A Teacher in English Language Teaching (ELT). International Journal of Educational Science and Research (IJESR). Vol. 7, Issue 1 pp. 1-4.

http://www.researchgate.net/publication/312610317
Zhu, Erping. (2006). Interaction and Cognitive Engagement: An Analysis of Four Asynchronous Online Discussion. Vol 34, pp 451-480. 